\title{
Defining and Mapping Social Enterprises: Some Theoretical and Conceptual Perspectives for the Philippines (and Asia-Pacific)
}

\author{
Jose TiuSonco II \\ Senior Lecturer, University of the Philippines-National \\ College of Public Administration and Governance \\ Philippines \\ jotiusonco@gmail.com
}

\author{
Joel Mangahas \\ Senior Social Sector Specialist, Asian Development Bank; \\ Adjunct Professor, UP-NCPAG \\ Philippines
}

\begin{abstract}
This paper reviews theoretical and conceptual perspectives - and academic debates - towards enabling an institutional framework for social enterprises (SEs) to develop and grow. It advances approaches in defining and mapping SEs as well as in potentially operationalizing the Institutional Analysis and Development (IAD) framework of Ostrom. It locates the discussion of SEs within the context of 'reconceptualizing' the third sector/ social economy, and clarifies terminologies that are interchangeably used in academic and policy discourse - SE, social entrepreneurship and social innovation - leading to confusion among researchers and policy actors. It suggests some elements in defining SEs based on economic, social and governance dimensions (Defourny 2001, Defourny and Nyessens 2010) and a spectrum for mapping SEs building on the works of Alter (2007), Defourny and Kim (2011) and European Commission (2016). Finally, it concludes with policy implications in defining SEs and in enabling the policy and institutional framework for SEs at the country level. One important policy implication of this exercise relates to enabling 'what a social enterprise can be' rather than prohibiting or limiting its growth and development by prescribing a restrictive definition of "what a social enterprise is.'
\end{abstract}

Keywords-Defining Social Enterprises, Mapping Social Enterprises, Philippines

\section{INTRODUCTION}

There is a need to provide policy-relevant knowledge towards enabling a policy and institutional framework to foster social enterprise (SE) and development. In the Philippines, it is envisaged to strengthen the role of government as enabler, regulator and financier; and intermediaries as capacity builders towards SEs growth and development at scale (Mangahas 2015). However, this process is not an easy and simple task as transplanting, transporting or creating a particular model of SE for policy adoption. Defourny and Nyssens (2010, 49) cautioned not to simply "support development of SE by exporting US or European approaches; if SEs are not embedded in local contexts, they will just be replications of formula that will last only as long as they are fashionable."

Institutional reforms have to be pursued based on in-depth institutional analysis and its mechanisms of change be embedded in the structures and processes at the country level. It requires both a broad macro-institutional context and microinstitutional analysis of the rules, actors and incentives to understand how they interact in 'action situation' and the processes of SE and social entrepreneurship leading to social innovation outcome/s - social and economic values.

Moreover, there are nuances of the concepts and models in global regional context that should be taken into account when defining and/or establishing boundaries in mapping an SE ecosystem. There are also competing views on SE as either a not-for-profit or for-profit organization that should be put in context.

This paper aims to provide some theoretical and conceptual perspectives - and academic debates - towards enabling SEs growth and development. It advances attempts at defining, mapping SEs and in potentially operationalizing Institutional Analysis and Development (IAD) framework.

\section{SOCIAL ENTERPRISES AND RE-CONCEPTUALIZING THE THIRD SECTOR/ SOCIAL ECONOMY}

The study of SE may have to be seen as part of the reconceptualization and broadening of the third sector or 'beyond the typical non-profit institutions' instead of introducing a "new sector" or what others might call "the fourth sector." Drawing on the divergences and convergences of SEs in the US and European research traditions, Defourny and Nyssens (2010) provide a compelling case to locate the conception of SE and social entrepreneurship within the academic discourse embedded in the third sector (see also Defourny et al. 2016; Borzaga and Defourny 2001). They argue that the 'public purpose' dimension of SE combined with relaxed nonprofit distribution constraint...enlarges the third sector conceptualization based on strictly non-profit institutions. As such, SE "should not appear as an additional component of the third sector that seems quite distinct from non-profits and cooperatives" - more often a SE adopts either a cooperative or non-profit legal form (1551).

In recent years, studies attempting to provide a global perspective of SEs are shaped or influenced by historical 
legacies, type of government, level of economic development and maturity of civil society (e.g., Kerlin 2017, 2013, 2010) as well as the key role of public policies in shaping models (e.g., Defourny and Nyssens 2016, 2010; Defourny and Kim 2011; Nyssens 2006) at the regional and country levels. Defourny and Kim (2011) observed that the emergence of SEs in select countries in East Asia emanate from a strong state linking with civil society, public policies and the involvement of cooperatives and non-profit organizations. These features are somehow similar to the experience in Western Europe where SEs position at the "crossroads of market, public policies [state] and civil society" (quoting Nyssens 2006). In spite of establishing some commonalities in the countries of study, they recognized a certain degree of variation and diversity of SEs at the country level.

SE development experience in Western Europe and East Asia seem to diverge from the US approach; the latter shows a minor role of the state and stronger relationship between the market (e.g., through foundations) and civil society. There is still a scant literature on SE in Southeast Asia nations (ASEAN), much less draw some comparative perspective visà-vis other regions. However, by broadly looking at their historical legacies, types of government, levels of development, and civil society maturity as well as the dynamics and interaction of the state, market and civil society, it can be surmised that ASEAN sub-group in Asia-Pacific region may provide commonalities and differences in models of SEs both at the group and country levels.

\section{SOCIAL ENTERPRISES AND DEVELOPMENT: FRAMING AND APPLYING OSTROM'S IAD FRAMEWORK}

Broadly, SE and development may be framed as pursuing democratic governance (social economy approach) through economic activity (entrepreneurial and productivity) involving "public purpose" organizations (non-profit approach) at the local level towards community development. It is a process of bridging social economy and non-profit approaches closer to each other, thereby pursuing more balanced social and economic values.

Understanding and scoping the universe of the SE sub-sector is perhaps the initial step towards enabling a policy and institutional framework for them to flourish and develop at the country level. However, there are conceptual and technical constraints to be able determine the exact number or close to it. First, interchangeably using the term SE with social entrepreneurship and social innovation has created a certain degree of confusion among stakeholders. Second, the lack of or loose operational definition limits the ability to identify SEs. And third, there is limited and disparate data profiling their identity and existence.

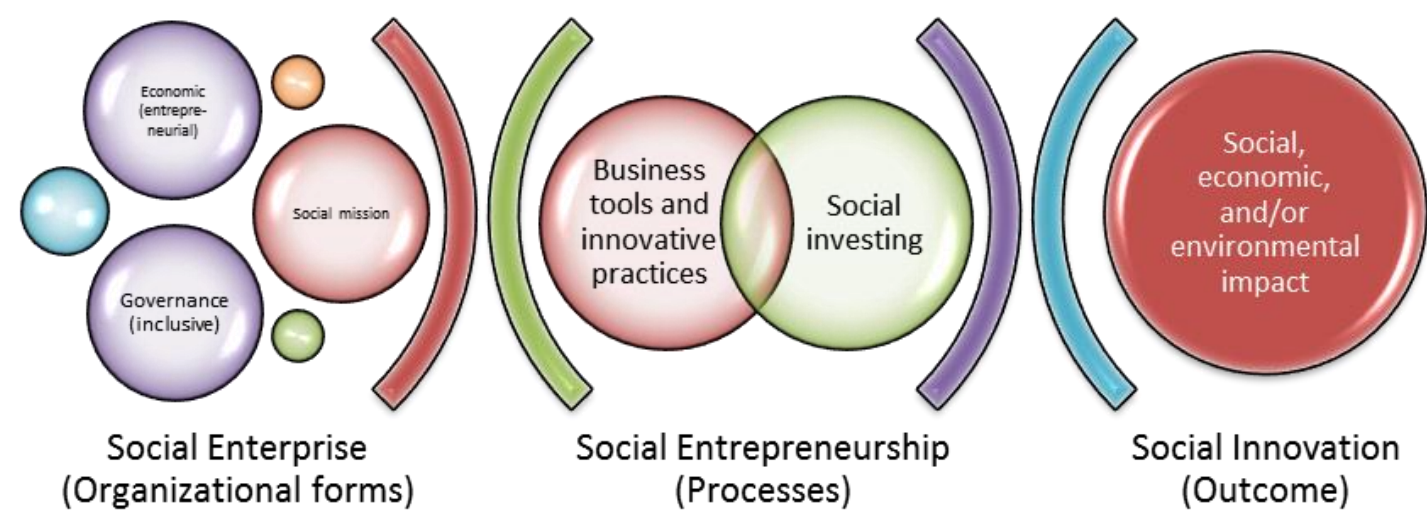

Figure 1. Phase of Enabling Social Enterprise and Developement

Source: Authors

Based on accumulated knowledge, Figure 1 above attempts to provide a stylized representation of the three terms used in the academic and policy discourse referred here as the phases of enabling SEs and development. SE refers to organizational forms with a social mission (value) engaged in economic activities (purpose) and managed through participatory and inclusive decision-making processes (governance structure) with a high degree of autonomy. Social entrepreneurship relates to resources units, processes employing business tools and innovative practices interfaced with social investing, thereby driving social mission with financial sustainability. Social innovation is the outcome of the two phases creating an impact on social and/or economic values with environmental sustainability as an underlying goal.

To operationalize this, Table 1 provides the dimensions of SE - economic/ entrepreneurial, social and governance structure with indicative criteria to which each dimension can be measured or evaluated. SEs generate revenues from entrepreneurial activities and/or may receive resources from public or private entities; but they are autonomous in makingdecisions. A legal framework may "prohibit" or "limit" the 
distribution of profit or surplus. The 'governance structure' and guarantee for social mission' are key elements of SEs.

Table 1: Dimensions of Social Enterprises

\begin{tabular}{|l|l|}
\hline Dimension of SEs & Criteria \\
\hline Economic and & 1. a continuous activity producing goods and/or selling services \\
entrepreneurial & 2. a significant level of economic risk \\
& 3. a minimum amount of paid worked. \\
\hline Social dimension & 4. an explicit aim to benefit the community \\
& 5. an initiative launched by a group of citizens or civil society organization \\
& 6. a limited profit distribution \\
\hline Governance structure & 7. a high degree of autonomy \\
(participatory governance) & 8. decision-making power not based on capital ownership \\
& 9. participatory nature, which involves various parties affected by the activities \\
\hline
\end{tabular}

Source: Defourny and Nyssens 2010; see also Italy’s Ecosystem Assessment for the operational definition of SE dimensions.

SE's institutional pathway may be anchored on values of economic efficiency, equity through fiscal equivalence, redistribution equity and sustainability on the one hand; and accountability and conforming to local values through participatory governance on the other hand. These values are outcomes of interest consequential to institutions -rules, actors and incentives - as they interact with each other in an "action situation" (see Ostrom 2011, 2005) that can be applied in SE phenomenon. However, it requires an in-depth institutional analysis to understand the 'rules' and 'norms,' e.g., where do they come from, working rules and rules-in-use (Ostrom 2011, 18).

In doing so, the IAD of Elinor Ostrom can be applied to cover the broader contextual variables and micro-institutional variables of SE and development at the country level. With SE and development as empirical phenomenon or 'action situation', it may employ Ostrom's IAD framework by analyzing the following variables: i) size, productivity, and predictability of SE system; ii) extent of mobility of resource units; iii) existence of collective-choice rules that the SEs may adopt authoritatively in order to change their own operational rules; and iv) four attributes of actors, i.e., number, existence of leadership, knowledge about SEs, and importance of SEs to actors.

At the outset, Ostrom $(2011,19)$ purports that the "stability of rule-ordered actions depends upon the shared meaning assigned to words used to formulate a set of rules" and that "shared meaning may change with time, technology, shared norms and circumstances." Unfortunately, the meaning of SE in Asia-Pacific region remains to be too broad, elusive, murky and undefined. Arguably, there is an "identity crisis" of SEs in Southeast Asia. Despite of this five models of SEs in East Asia emerge as: trading non-profit organization, work integration SE, non-profit co-operative, non-profit and for profit partnership, and community development enterprise (see Defourny and Kim 2011).

In the Philippines, recent studies have pointed the need to formulate an operational definition for SEs to inform policymakers and engender better understanding by other stakeholders (e.g., Mangahas 2015, British Council 2015). While earlier studies and popularization of SEs (e.g., Dacanay 2013, 2012, 2004; ADB 2011) put forward definitions that are either too broad or too narrow, which make it challenging to operationalize, i.e., theoretically, empirically and/ or for adoption in public policy. Box 1 provides some relevant operational definitions of SE for the Philippines to consider and/or build upon.

Box 1: Some Operational Definitions of Social Enterprise Austin et al. (2004, xxv): "any kind of organization or undertaking engaged in activities of social value, or in the production of goods and services with an embedded social purpose regardless of legal form." - SE Knowledge Network from by Latin American business schools and Harvard Business School (in Defourny and Nyssens 2010, 47)

Defourny and Nyssens (2008, 204): "SEs are not-for-profit private organizations providing goods or services directly related to their explicit aim to benefit the community. They general rely on collective dynamics involving various types of stakeholders in their governance bodies, they place high value on their autonomy and they bear economic risks related to their activities."

Impact Investment Shujog Ltd. (in ADB 2011, 37): "SEs are either not-for-profit or for-profit organizations that exist primarily to create specific positive social or environmental impact and use market-based approaches to achieve social or environmental objectives. SEs pursue their mission while maintaining financial sustainability."

Kerlin (2013, 84): "use of nongovernmental, market-based approaches to address social issues and a business source of revenue for many socially-oriented organizations and activities"

Monroe-White and Coskun (2017, 31): "SEs are organizations with an explicit social purpose that also generate revenue from sales." In mapping SEs, one may look at the value orientation (social and/or environmental), ownership status, and amount of income generated through sales of organization. This is based on Alter 2007 and 2009 GEM data as deduced by Monroe-White and Coskun (2017).

Dacanay $(2013,2012)$ : Social enterprises are social missiondriven wealth creating organizations that have a double or triple bottom line (social, financial and/or environmental), explicitly have as principal objective poverty reduction/alleviation or improving the quality of life of specific segments of the poor, and have a distributive enterprise philosophy." 
On the one hand, SE operational definition should not be limited within the purview of "cooperatives" operating a business or providing goods and services for their own members and explore the potential of working with nonmembers or outside market and networks. On the other hand, it should not be too broad that it blurs the distinction between the market/ private sector and civil society or third/non-profit sector. Therefore, it is imperative to adopt or develop a definition that minimizes the potential of excluding other organizational forms and models of SEs. The ownership of SEs should also be clarified whether it will take a not-for-profit entity or business entity, e.g., sole proprietorship, partnership or corporation.

The literature offer pointers on what a SE is "not." First, they are not confined to traditional cooperatives where the members are the owners and consumers or beneficiaries. Second, they are not mainly focused on redistribution of financial flows and 'grant-giving,' rather they are directly involved in production and selling/ trade of goods and/or provisions services. And third, they do not only serve the poor or marginalized, rather SEs shift the provision of 'needs' from owners and members to the entire community, and pursue 'interests' from mutual goals to 'general interest' (Borzaga et al. 2014).

As such, SEs may also provide a variety of services of general interest, e.g., healthcare, childcare, education, water, among others. In Europe, there is wide variety of services based on public policies. For instance, Romania and Hungary focus on health, social work and education; Sweden and UK on community, social and related services; and Italy on work integration and welfare provision (ibid. 7).

In synthesis, SE and development phenomenon is neither focused on pure public good, non-profit activity nor marketbased solution to address social problems or improve living conditions. Rather, it is a "hybrid" approach combining social mission; business methods and innovative practices, social investing including intermediation and financing; and governance systems at the community level to attain a collective social and/or economic impact - a social innovation. It involves dynamic organizations that produce, sell/ trade or deliver goods and/or services with explicit social mission or benefit to the community where it operates.

\section{4. MAPPING SOCIAL ENTERPRISES IN THE PHILIPPINES}

In mapping SEs, two possible approaches are put forward in establishing the boundaries for SEs to be identified, mappedout, and individually measured as well as their collective impact analyzed. First is to adopt the three SE models building on diverse regional contexts, particularly from the US and European practices as conceptualized by Jacques Defourny (2016). These are: i) non-profit entrepreneurial model and a social cooperative model naturally stem from the third sector/ social economy; ii) social business model may appear through quite advance corporate social responsibility strategies in the private sector when the social mission is not just instrumental to profit maximization; and iii) public-sector SE model shaped and controlled by quite specific public policies.

Second is to locate "what a social enterprise can be" following a hybrid spectrum developed by Alter (2007) or "public purpose" organizations between traditional non-profit and traditional for-profit as shown in Figure 2. The three SE models of Defourny and Nyssens (2016) can be plotted in the spectrum of SE of Alter 2007. Monroe-White and Coskun (2017) study suggests mapping of SEs by considering value orientation (social and/or environmental), ownership status, and amount of income generated through sales. However, lack of data is a major constraint and the enormous number of potential SEs and de facto SEs, e.g., traditional non-profits, can render the exercise very challenging.

Furthermore, SE per se can initially be operationalized and mapped-out as either legally-recognized SEs or de facto SEs following Italy's SE and ecosystem mapping report as indicated in Table 2. This has been expanded to include five models of SEs derived from case studies in East Asia being trading non-profit organization, work integration SE, nonprofit co-operative, non-profit and for profit partnership, and community development enterprise (see Defourny and Kim 2011).

\begin{tabular}{|c|c|c|c|c|c|}
\hline $\begin{array}{l}\text { Traditional } \\
\text { nonprofit }\end{array}$ & $\begin{array}{l}\text { Nonprofit } \\
\text { with income- } \\
\text { generating } \\
\text { activities }\end{array}$ & $\begin{array}{l}\text { Social } \\
\text { Enterprises }\end{array}$ & $\begin{array}{l}\text { Socially } \\
\text { responsible } \\
\text { business }\end{array}$ & $\begin{array}{l}\text { Corporation } \\
\text { practicing } \\
\text { social } \\
\text { responsibility }\end{array}$ & $\begin{array}{l}\text { Traditional } \\
\text { for-profit }\end{array}$ \\
\hline & \multicolumn{2}{|c|}{$\begin{array}{l}\text { Mission motive } \\
\text { Stakeholder accountability } \\
\text { Income reinvested in social } \\
\text { programs or operational costs }\end{array}$} & \multicolumn{3}{|c|}{$\begin{array}{l}\text { Profit-making motive } \\
\text { Shareholder accountability } \\
\text { Profit redistribution to shareholders }\end{array}$} \\
\hline
\end{tabular}

Figure 2: Spectrum of Social Enterprises Source: Adapted from Alter 2007. 
Table 2: Typology of Social Enterprises

\begin{tabular}{|l|l|l|l|}
\hline \multicolumn{2}{|l|}{ Legally-recognized SEs } & De facto SEs \\
\hline Social cooperatives & Social enterprises (ex lege) & Associations and & Traditional cooperatives \\
1. Type A: deliver social, & 1. Type A: trading nonprofit & foundations with market & activities and explicit social \\
health and education services & (e.g., multi-purpose) \\
2. Type B: work integration & 2. Type B: non-profit and for & mission & \\
SE (WISE) & $\begin{array}{l}\text { 3rofit partnership } \\
\text { 3evelopment enterprise }\end{array}$ & & \\
& & & \\
& & & \\
\end{tabular}

Many SEs take the legal form of cooperatives or non-profit (Defourny and Nyssens 2010). In fact, initial mapping of SEs in the Philippines identified cooperatives to represent $93 \%$ out of about 30,000 so-called SEs (Dacanay 2012). Mapping of SEs in Italy identified social cooperatives $(11,264)$ and ex lege SEs $(1,348)$ to have met the eligibility criteria for SEs by $100 \%$; of the 6,220 foundations and 269,353 associations only $35 \%$ and 28 have met the criteria, respectively. Therefore, understanding the landscape, dynamics and relationship of cooperatives at the country level is relevant to the institutional analyses of SEs. There is also the need to understand the potential shift or conversion of mainly members' consumer- or market-orientation to social innovation or a balance between the two in promoting SEs.

\section{CONCLUSION AND POLICY IMPLICATIONS}

In conclusion, formulating an operational definition and subsequent policy and institutional reform for social entrepreneurship and social innovation would benefit from macro- and micro-institutional analyses of SEs at the country level. One important policy implication of this exercise is enabling 'what a social enterprise can be' rather than prohibiting or limiting its growth and development by prescribing a restrictive definition of "what a social enterprise is.'

The policy and institutional framework should enable the transition or conversion of traditional non-government organizations (NGOs), cooperatives, and nonprofit organizations and even micro- small- and medium enterprises (MSME) to become SE; thereby embracing the value of social entrepreneurship and social innovation. On the one hand, they have the historical experience and cultural knowledge on the ground in pursuing community development; on the other hand they will continue to be key actors in governance processes both at the national and subnational levels.

Moreover, it should enable emerging SEs to work in collaboration with traditional NGOs that have become key actors in community development. Equally important, it should encourage the entry and emergence of new SEs; support the rise of both experienced businesspersons and young social entrepreneurs into the social entrepreneurship space.

Below are some indicative directions towards mapping and profiling of, and subsequently strengthening policy and institutional support for SEs in the Philippines.
Set eligibility criteria for SE in the Philippines, initially based on the dimensions and typology of SEs (see Tables 1 and 2) and, undertake a mapping assessment of the ecosystem of SEs to approximate number of eligible organizations

ii. Enable registration and/or transition of traditional cooperatives, non-profit and even MSMEs to become SE

- Set period and requirements for registration and renewal

- Harmonize database system for registration and profiling, e.g., Cooperatives Development Authority, Securities and Exchange Commission, Department of Trade and Industry, among others

iii. Support measures for development of existing organizations, SE start-ups and long-term work and social integration (e.g., with disabilities, elderly, welfare services), and other local services provision such as healthcare, education, access to water, among others

- Tax incentives of non-profits, access to guarantee fund, fee-for-service from either public sector or private sector

- Classify SEs as MSME to enable them to tap MSME financing facility

- Incentivize rather than subsidize the poor to participate in local economic activities through SEs, e.g., exemption from health insurance contribution among workers

iv. Engage academic and research institutions both at the central and regional levels.

\section{REFERENCES}

[1] Alter, K. Social enterprise typology. Virtue Ventures LLC, 2007.

[2] Asian Development Bank. Impact Investors in Asia. Mandaluyong: Asian Development Bank, 2011.

[3] Borzaga, C, and J. Defourny. The Emergence of social enterprise. London: Routledge, 2001.

[4] Borzaga, Carlo, Riccardo Bodini, Chiara Carini, Sara Depedri, Guilia Galera, and Gianluca Salvatori. "Europe in transition: the role of social cooperatives and social enterprises." Euricse Working Papers, 691 14, 2014.

[5] British Council. A review of social enterprise activity in the Philippines. British Council Philippines, 2015.

[6] Dacanay, Marie Lisa. Creating a social space in the market: social enterprise stories in Asia. Makati: Asian Institute of Management, 2004. 
[7] - Social enterprises and the poor: enhancing social entrepreneurship and stakeholder theory. Denmark: Copenhagen Business School, 2012.

[8] Dacanay, Marie Lisa. Social enterprises and the poor: transforming wealth. Manila: Institute for Social Entrepreneurship in Asia, 2013.

[9] —. "Understanding social entrepreneurship." January 20, 2013.

[10] Defourny, Jacques, and Martha Nyssens. "Fundamentals for an international typology of social enterprise models." ICSEM Working Papers (The International Comparative Social Enterprise Models (ICSEM) Project), 2016.

[11] Defourny, Jacques, and Marthe Nyssens. "Conceptions of social enterprise and social entrepreneurship in Europe and the United States: Convergences and Divergences." Journal of Social Entrepreneurship (Routledge) 1, no. 1 (2010): 32-53.

[12] Defourny, Jacques, and Shin-Yang Kim. "Emerging models of social enterprise in Eastern Asia: a cross-country analysis." Social Enterprise Journal, 2011.

[13] Defourny, Jacques, Kirsten Gronbjerg, Lucas Meijs, Marthe Nyssens, and Naoto Mauchi. "Voluntas symposium: comments on Salamon and Sokolowski's re-conceptualization of the third sector." Voluntas (Springer) 27 (2016): 1546-1561.

[14] European Commission, Directorate-General for Employment, Social Affairs and Inclusion. "Mapping study on social enterprises ecosystems: updated country report on Italy." 2016.

[15] Kerlin, Janelle. "A Comparative Analysis of the Global Emergence of Social Enterprise." Voluntas: Intenriatonal Journal of Voluntary and Nonprofit Organizations 21, no. 2 (2010): 162-179.
[16] Kerlin, Janelle. "Conclusion: revising the macro-institutional social enterprise framework." In Shaping social enterprise: understanding institutional context and influence, by Janelle Kerlin, 277-305. UK: Emerald, 2017.

[17] Kerlin, Janelle. "Defining social enterprise across different contexts: a conceptual framework based on institutional factors." Nonprofit and Voluntary Sector Quarterly 42, no. 1 (2013): 84-108.

[18] Kerlin, Janelle. "Social enterprises in the United States and Europe: understanding and learning from the differences." Voluntas: International Journal of Voluntary and Nonprofit Organizations 17, no. 3 (September 2006): 247-263.

[19] Lepoutre, Jan, Rachida Justo, Siri Terjesen, and Niels Bosma. "Designing a global standardized methodology for measuring social entrepreneurship." Small Business Economics (Springer) 40, no. 3 (April 2013): 693-714.

[20] Mangahas, Joel. Developing an enabling environment for social enterpreneurship in the Philippines. unpublished manuscript, 2015.

[21] Ostrom, Elinor. "Background on the Institutional Analysis and Development Framework." The Policy Studies Journal 39, no. 1 (2011): 7-26.

[22] Ostrom, Elinor. "Behavioral approach to the rational choice theory of collective action." American Political Science Review 92, no. 1 (1998): $1-22$.

[23] —. Understanding institutional diversity. Princeton, New Jersey: Princeton University Press, 2005. 